\title{
CUSTOMER LOYALTY ON HALAL MEAT PRODUCT: A CASE STUDY OF INDONESIAN LOGISTICS PERFORMANCE PERSPECTIVE
}

\author{
Ilyas Masudin* \\ University of Muhammadiyah Malang \\ Faradilla Witha Fernanda \\ University of Muhammadiyah Malang \\ Fien Zulfikarijah \\ University of Muhammadiyah Malang \\ Dian Palupi Restuputri \\ University of Muhammadiyah Malang
}

\begin{abstract}
The purpose of this article is to determine the influence of halal supplier's service quality, halal logistic performance, perceived service value and customer satisfaction to customer's loyalty on halal meat products at non-moslem areas. This paper uses quantitative method that is done by collecting data from 90 respondents and analyzed using structural equation modeling (SEM) to determine the correlation between variables. The study found a significant influence occurs on the relationship halal supplier's service quality to halal logistic performance, halal supplier's service quality to perceived service value, halal logistic performance to customer satisfaction, perceived service value to customer satisfaction, and customer satisfaction to customer loyalty. The insignificant influence happened at halal supplier's service quality to customer satisfaction relation. This study contributes to the halal logistic topics that are still rarely studied, especially by taking the place of research in Indonesia which is a majority area of Muslims and also has some non-Muslim majority areas. The study focused on the comparative influence of halal logistics performance on consumer loyalty of raw and processed meat products for Muslims in Indonesian non-muslim majority area. The results of this study indicate that there is a significant relationship between the quality of halal supplier services and halal logistics performance, the quality of halal supplier services with perceived service value. In addition, it also found the effect of halal logistics performance on customer satisfaction, perceived value of service to customer satisfaction, and customer satisfaction with customer loyalty. Furthermore, there is a significant effect on the quality of halal supplier services on customer satisfaction relationships.
\end{abstract}

Keywords: Customer's loyalty, halal logistic performance, halal supplier's service quality, customer satisfaction.

Received: 25 May 2019

Accepted:30 December 2019

\footnotetext{
* Corresponding Author: Ilyas Masudin, Department of Industrial Engineering, University of Muhammadiyah Malang, Jl. Raya Tlogomas 246 Malang, 65144, Indonesia. Email: masudin@umm.ac.id.
} 


\section{INTRODUCTION}

Customer loyalty is the primary goal of every company's marketing division. This is because a high level of loyalty is able to maintain a more stable level of income as a result of creating strong relationships between customers and companies (Duygun, 2015). In addition, as the product continues to be sold, the company's market share will continue to increase (Lin \& Wang, 2006). Therefore every company tries to maintain its customer loyalty level because losing loyal customers is more expensive than the cost to get new customer (Cachon \& Feldman, 2015; Keaveney, 1995). One way to maintain customer loyalty is to improve logistics performance. The definition of logistics performance is the ability of logistics providers to consistently distribute products with the appropriate time and cost frames (Bowersox, Closs, \& Cooper, 2002). In term of the relation of the relationship between logistic performance and loyalty, and Richey, Daugherty and Roath (2007) mentioned that the improvement of product quality as results of improved logistic performance will result in a greater customer satisfaction and implications for loyalty. It is also mentioned by Stank, Goldsby, Vickery, and Savitskie (2003) that logistics creates value for consumers by meeting customers' demands on a cost-effective basis.

The majority of the population in Indonesia is Muslim, so halal products become a mandatory requirement for each food producer. Logistics performance plays an important role in maintaining the halal guarantee of a product. One of the most vulnerable products is halal meat products. Meat is particularly vulnerable to non-halal only due to the wrong animal slaughter or because of little contamination with non-halal materials. Because of its vulnerability, halal meat products become one of the high demand products in non-Muslim majority areas because of the difficulty of obtaining halal meat. In a previous study conducted by Jusmaliani and Nasution (2009) and Masudin, Fernanda, Jie, \& Djajadikerta (2018) comparing the behavior of halal meat consumption among Indonesian Muslim consumers in some Indonesian cities and Melbourne found a different consumer behavior in buying halal meat in Muslim and non-Muslim majority. Moreover, the study by Ali, Xiaoling, Sherwani and Ali (2017) indicates that there is a positive relationship between personal attitude and halal meat consumption for Muslims living in China.

In Muslim majority areas, halal logistics is the main requirement and considers a liability if the seller wants to market the product. However, in non-Muslim majority areas, halal logistic is not a major requirement and this makes it difficult for Muslim customers in the area. Sometimes because of halal doubt, Muslim customers in non-Muslim areas will not buy the product until they are convinced that the product is halal. This was demonstrated in a survey conducted by Stitou \& Rezgui (2012) in a Muslim community in France, whose results show that $56 \%$ of the 223 Muslim respondents will not buy a product if they are in doubt about the halal product. In contrast, $87 \%$ of respondents are willing to pay more for products that are completely halal. This data is the basis of the importance of halal logistics for Muslim customers, especially those in non-Muslim areas. If logistics performance is improved, especially with the objective of maintaining halal product quality, it will be easy for a supplier or retailer to sell halal meat to improve customer satisfaction and loyalty.

Davis (2006) discusses loyalty and role of logistic service in creating customer loyalty. In addition to finding that the role of logistics service is very strategic in creating loyalty, the research also states that between customer satisfaction and loyalty occurs more complex relationship. The satisfaction factor is not enough to influence future customer behavior, but it takes an emotional 
bond and trust in the relationship between consumers and stores. This factor should be given the first time a customer is served, thus creating a positive customer behavior.

This study investigates the effect of halal supplier service quality, halal logistic performance, perceived service value and customer satisfaction on customer's loyalty of halal meat products at non-Muslim areas. The results of this study can be used for decision-makers in the field of halal supplier or retail to decide the logistics services and appropriate standards to be used especially for Muslim customers in non-Muslim areas. The originality of this research is taken from the lack of research that discusses the relationship of halal logistics and customer loyalty in Indonesia, especially in the field of halal meat. Halal logistics itself is still a new topic for academics and practitioners (Jaafar, Faisol, Rahman, \& Muhammad, 2016). The theme of the research on halal meat logistic and marketing still addresses the topic of customer perception (Alqudsi, 2014; Tieman, Ghazali, \& Van Der Vorst, 2013), market analysis (Lever \& Miele, 2012), and behavioral retailers (Kalantari Shahijan, Rezaei, Nigel Preece, \& Khairuzzaman Wan Ismail, 2014). The results of this study can also be developed as a basis for further research in the field of halal logistics and marketing.

\section{LITERATURE REVIEW}

There are four factors tested as determinants, namely customer satisfaction, perceived service value, halal supplier service quality, and halal logistic performance. The conceptual model and hypotheses proposed in this study are also discussed in this literature review section.

\subsection{Halal Supplier Service Quality}

The service quality context emphasized in this study is halal suppliers' service quality with the characteristics of halal logistic performance. Thus, the modified SERVQUAL scale dimensions by Bienstock, Mentzer, and Bird (1997) are used to measure service quality in the context of logistics performance. These two-dimensional divisions are also used by Mentzer et al.(2004), about their research in manufacturing industry. The elements are:1). information system availability plays an important role in connecting between customers and providers (Man, 2006). The nature of the information provided should help customers to easily choose products, either information provided offline or online (Liang, 2008; Ya'kob \& Jusoh, 2016). The Supplier shall ensure that the information provided is sufficient for the consumer, correct and assured of its content (Chen \& Wells, 2000). 2). A smooth supply of halal products helps to maintain customer satisfaction. Customer is more confident to suppliers who are able to maintain the availability of its products. In a study by Kisperska-Moron (2005) found that consumers would feel satisfied if the required products are available. This point is supported by Mentzer and Williams (2001) which states that product availability is an important element in a manufacturing industry service quality.

After the measurement indicator is known, from previous research by Richey (2003), and Davis (2006), it is known that suppliers' service quality has a positive influence on logistics service performance. Such as Richey's (2003) research which results that good information technology and service (element service quality) can produce satisfactory logistic performance. In addition, perceived service quality also directly affects the perceived service value. This was reported in the study by Lee (2006). The dissertation of Lee (2006) shows that perceived service quality has a 
strong direct relationship with perceived service value. Further, Um, Chon and Ro (2006) in his marketing research found that service quality also had a direct positive relationship with customer satisfaction. Ketikidis et al. (2006) and Yang, Humphreys and McIvor (2006) from his research concluded that service quality can improve operational performance directly or indirectly (through logistics performance) resulting in customer satisfaction. Thus, we can posit the hypotheses:

H1: Halal supplier's service quality positively affects the halal logistic performance H2: Halal supplier's service quality has a positive effect on perceived service value H3: Halal supplier's service quality has a positive effect on customer satisfaction

\subsection{Halal Logistic Performance}

How to assess the logistics performance? Research conducted by Mentzer et al.(2001) found the logistics service quality concept that contains 9 concepts as a reference of logistic performance assessment, namely (1) personnel contact quality; (2) order release quantities; (3) information quality (4) ordering procedures (5) order accuracy; (6) order condition; (7) order quality; (8) order discrepancy handling and (9) timeliness (Bienstock, Royne, Sherrell, \& Stafford, 2008; Masudin, Fernanda, \& Widayat, 2018).

Personnel contact quality refers to the customer's perspective of how disrespectful personnel is to the problems and situations facing the customer. Information quality is customer perception of product information that is likely to be selected (Mentzer, Flint, \& Kent, 1999). Customers will make decisions easily if information on the product is available and complete (Mentzer et al., 2001). Order quality assesses how the product works (Novack, Rinehart, \& Langley Jr, 1994). Order condition means how well the condition of the goods ordered by the consumer (Mentzer, Rutner, \& Matsuno, 1997). The order discrepancy handling criterion is to assess how well the logistics provider handles product incompatibility if there is a mistake because the product is not appropriate (Rinehart, Cooper, \& Wagenheim, 1989).

Order accuracy refers to the exact delivery of goods in accordance with customer requests, including the order and quantity of the right goods, and no order replacement (Mentzer et al., 2001). Order condition means how well the condition of the goods ordered by the consumer (Mentzer et al., 1997). Order quality assesses how well the product works (Novack et al., 1994). The difference between order accuracy and order condition is: order quality assesses how well the product is made, the order accuracy assesses how complete the product is ordered, and the order condition assesses the level of damage to the product caused by the delivery process (Mentzer et al., 2001).

The order discrepancy handling criterion is to assess how well the logistics provider handles product incompatibility if the product is not appropriate (Rinehart et al., 1989). Finally, timeliness refers to the accuracy of the arrival of the product at the requested location of the consumer, or how long it will take from order to receipt of the product (Mentzer et al., 2001). These criteria are made based on research on conventional logistics. If applied to halal logistic, the requirements are adjusted so that ordered products are absolutely guaranteed to be halal. By using these references, the hypothesis is:

H4: Halal Logistic Performance positively affects overall customer satisfaction 


\subsection{Perceived Service Value}

Based on research from Wang et al.(2004), customer value is a strategic step in maintaining competitive advantage and has a strong effect on customer satisfaction and loyalty. In line with the results of this study, Gallarza and Saura (2006) stated that there are 2 reasons why perceived service value is important in marketing, first because the concept of value is the result of the development of two important dimensions of consumer behavior, the influence of economic and psychological factors. Second, the value helps explain the effects of consumer behavior, such as purchase intention (E. S.-T. Wang, Yu, \& Griffith, 2016), repeat purchasing (Fang, George, Shao, \& Wen, 2016), and product choice (C.-K. Lee, Yoon, \& Lee, 2007). Third, value is closely related to the construct of consumer behavior, for example satisfaction and loyalty. By looking at previous research, then in this section, the hypothesis is as follows:

H5: Perceived service value has a positive effect on consumer satisfaction.

\subsection{Customer Satisfaction}

Customer satisfaction is strongly related to consumer behavior such as word of mouth, repurchase intention, and positive feedback on firms (Sivadas \& Baker-Prewitt, 2000) that associated as indicators of customer loyalty (La, 2005). Furthermore, Wong, Lo, \& Ramayah (2014) found a positive results related to the relationship between perceptions of the use of technology and eloyalty and e-satisfaction. In a study conducted by Keaveney (1995) shows that customers can turn to other companies for various reasons caused by price, inconvenience, service failure, ethics, and so on. Most are related to customer dissatisfaction with the quality of service or other aspects offered. On that basis, the hypothesis prepared for this section is as follows:

H6: Customer satisfaction positively affects customer loyalty.

\subsection{Halal Meat Supply Chain and Conceptual Model}

This research focuses on halal meat products in the form of fresh meat and processed meat consumed by consumers after going through several stages of previous processes. Supply chain of halal fresh meat products and processed meat can be seen in the following figure.

Figure 1: Halal Meat Supply Chain

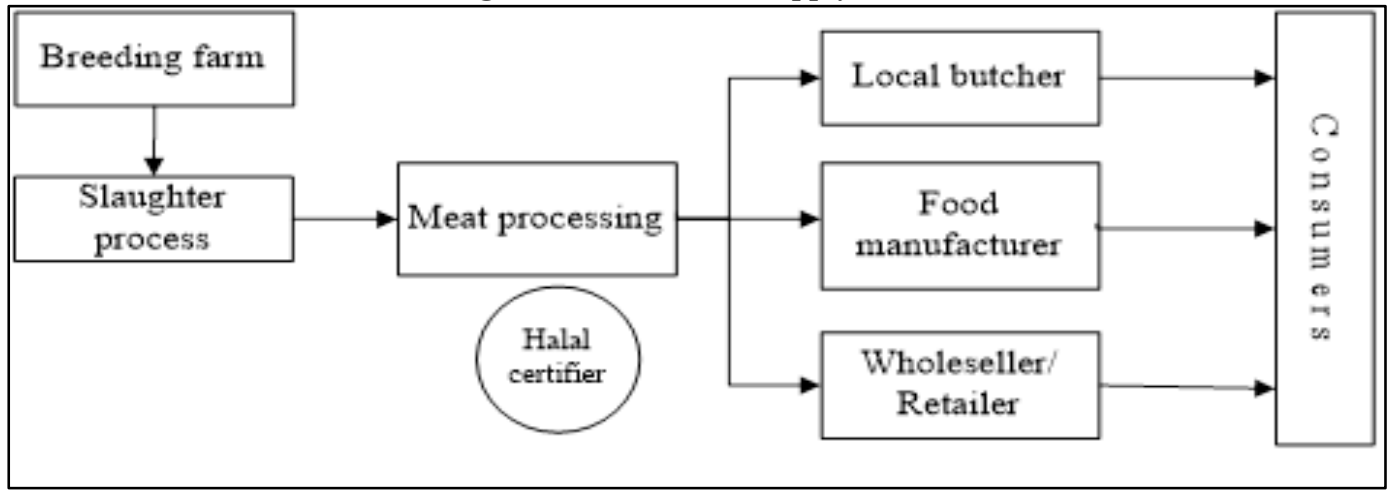


In this study, customer loyalty is formed from four previous constructs that are halal supplier's service quality, halal logistic performance, perceived service value, and customer satisfaction. The hypotheses presented in previous sections can be seen in relation to conceptual model in figure 2 .

Figure 2: Conceptual Model

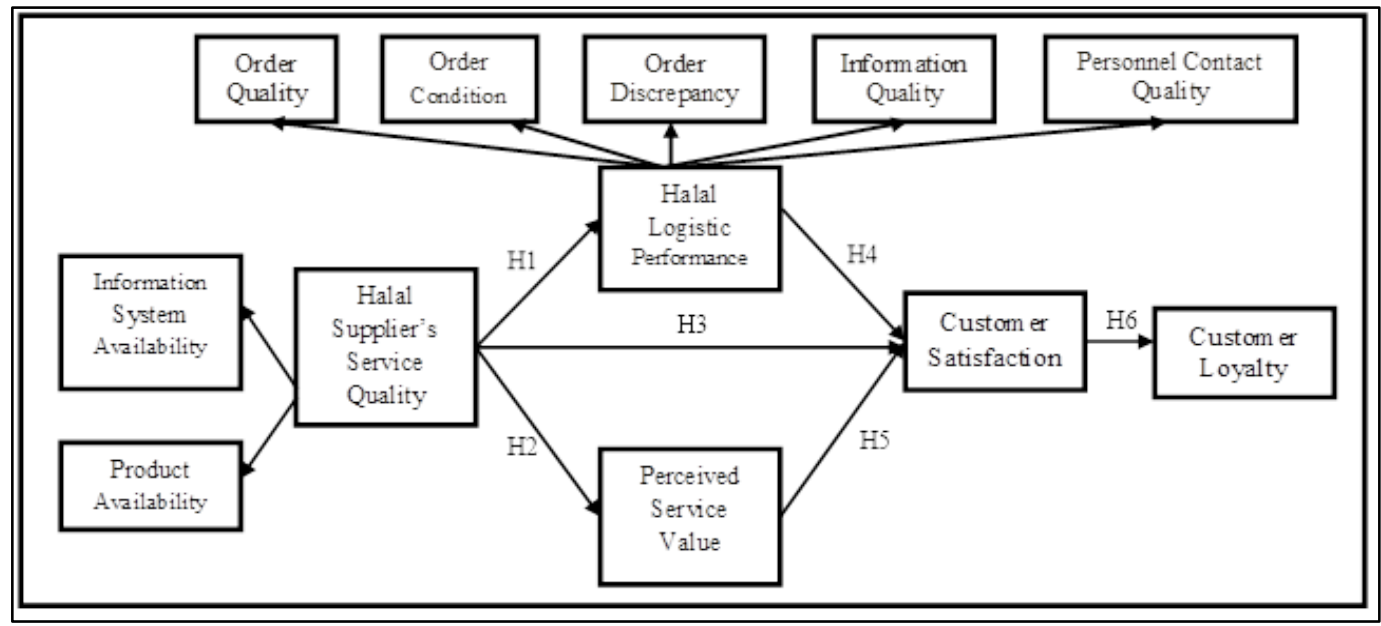

\section{METHODOLOGY}

The method used in this article is quantitative methods where data is collected by using questionnaires distributed to respondents. Then the data will be analyzed with Structural Equation Modeling (SEM) analysis tool to find out whether the hypothesis is relevant to the actual result of research.

\subsection{Research Sites and Sample}

The criteria in determining the location of this study is the area of non-Muslim majority area. In the area, there are modern and traditional markets on non-halal meat channels, sold together with halal meat. The selection of this location is because in the Muslim majority area tends to be very easy to get halal meat, so competition between stores is not focused on halal meat products but more to other marketing variables such as price, the convenience of shopping, and others. Conversely, if there are many stores at non-Muslim majority area sell non-halal meat, halal products will be the main focus considered by Muslim consumers. The sample criteria in this study are consumers who live in Bali island area and consume halal meat (chicken meat, beef, etc.) and purchase them in the modern market or traditional market, with the intensity of meat purchase at least 2 times a month. Sampling technique used in this study is purposive sampling. Hair, Black, Babin, Anderson and Tatham (2006) state that the sample size is at least 5 respondents for each measured item. This study has 10 measurement points which mean that at least 50 respondents have to fill out the questionnaire. 


\subsection{Definition and Constructing Measurements}

Measurement points in the questionnaire in this study are divided into 5 sections. Respondents are asked to choose from a scale of 1 to 7 to state how closely they are about the statements containing halal suppliers' service quality, halal logistics performance, perceived service value, customer satisfaction, and customer loyalty. Some studies related to customers behaviour on purchasing halal products such as Olya and Al-ansi (2018) and Awan, Siddiquei and Haider (2015) have used Likert scale from 1 (strongly disagree) to 7 (strongly disagree). Further explanation of the measurement variables can be seen in table 1, which also contains the measurement points for each variable. The research construct is shown in Figure 3.

Figure 3: Research Construct

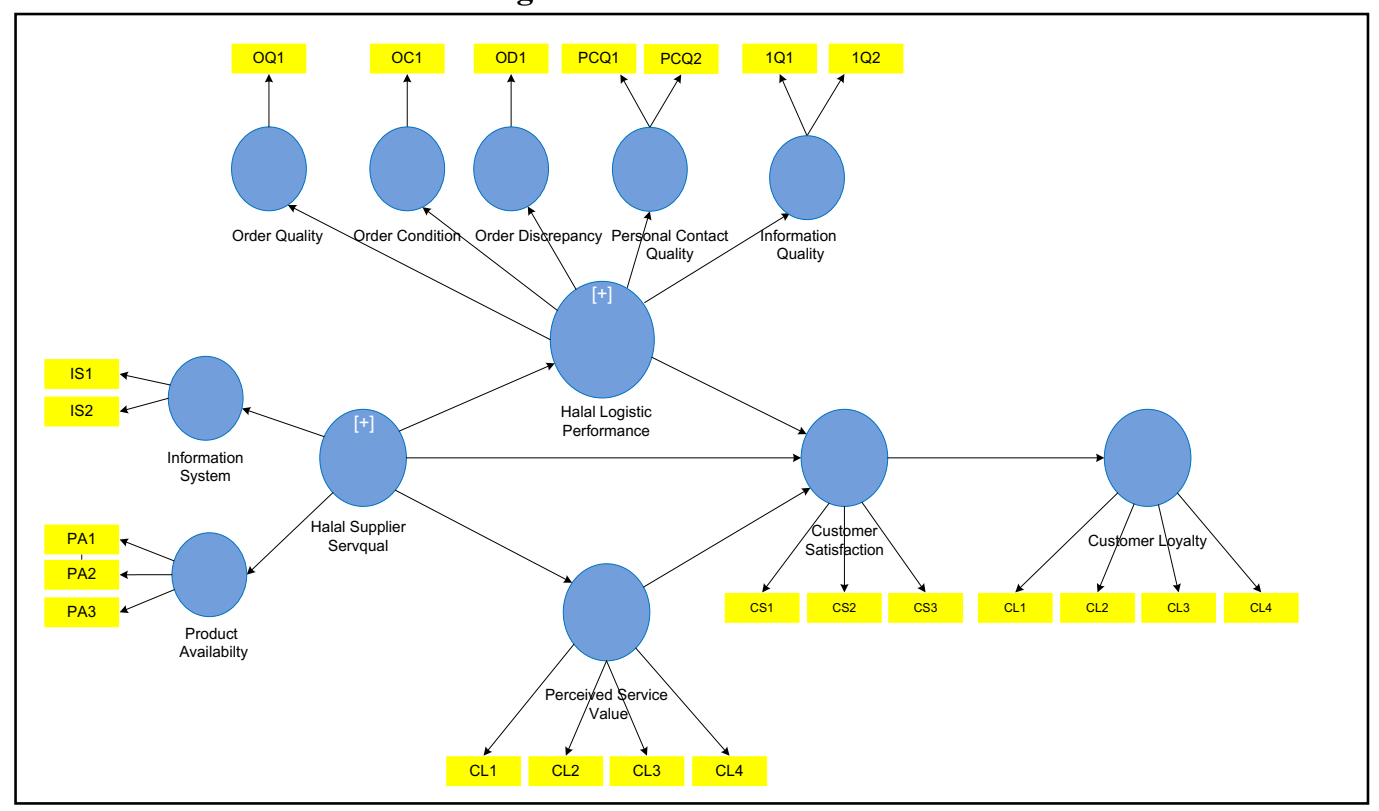

The analysis of the halal variables of supplier's service quality, halal logistics performance, perceived service value, customer satisfaction, and customer loyalty uses $95 \%$ confidence level, so the level of precision or limit of 5\% inaccuracy with the value of table is 1,96. The interpretation of this condition using $\mathrm{H}_{0}$ and $\mathrm{H}_{\mathrm{a}}$, where $\mathrm{H}_{0}$ is a hypothesis states no relationship between exogenous variables with endogenous and $\mathrm{H}_{\mathrm{a}}$ is the hypothesis that there is a relationship between exogenous variables with endogenous. 
Table 1: Definition and Points of Variable Measurement

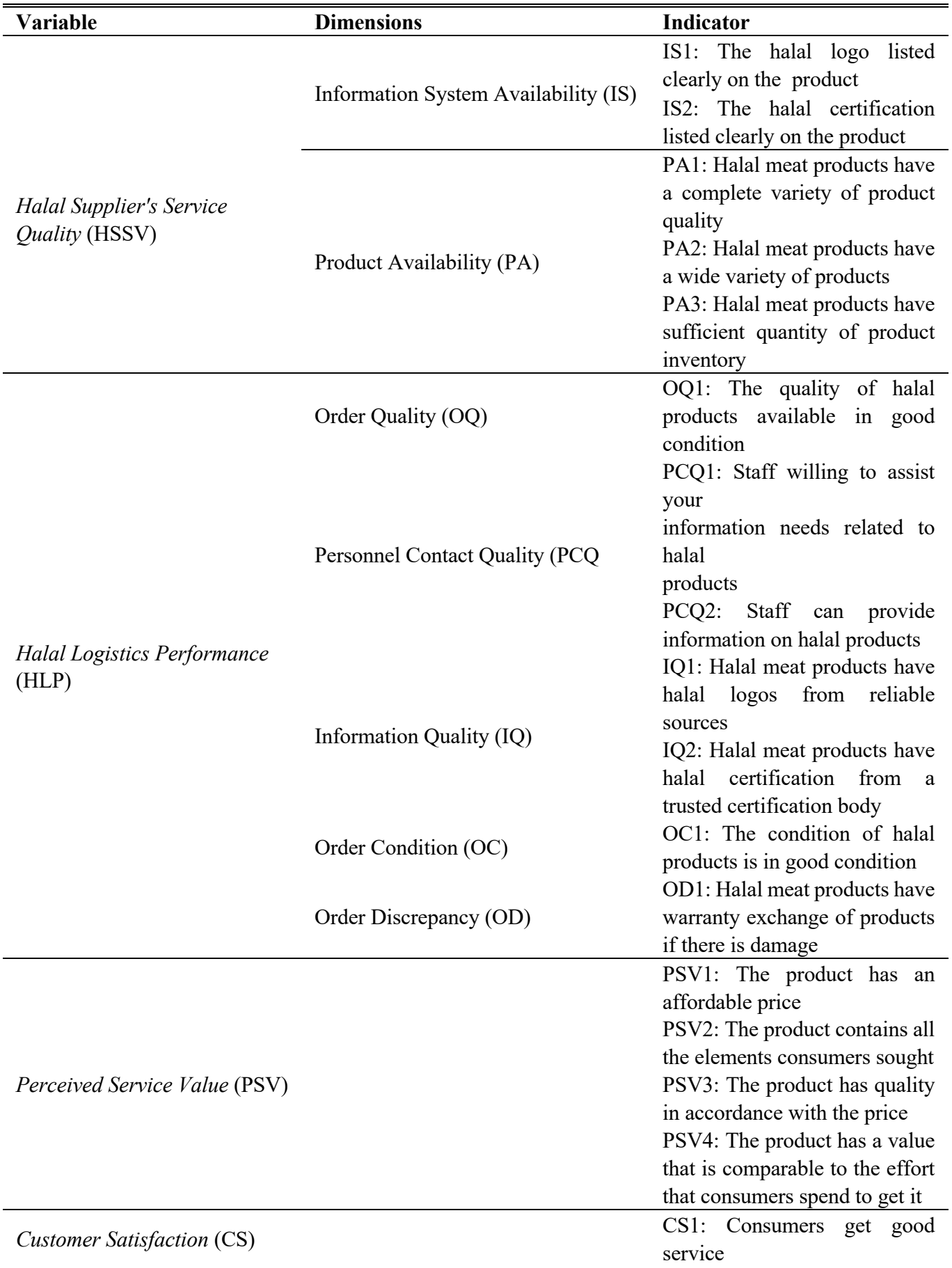




\begin{tabular}{|c|c|c|}
\hline Variable & Dimensions & Indicator \\
\hline & & $\begin{array}{l}\text { CS2: Services and products } \\
\text { obtained in accordance with the } \\
\text { value already paid } \\
\text { CS3: The services and products } \\
\text { that get the consumer feel good }\end{array}$ \\
\hline Customer Loyalty (CL) & & $\begin{array}{l}\text { CL1: Provide a positive } \\
\text { opinion on halal products and } \\
\text { services provided } \\
\text { CL2: Purchase the product } \\
\text { again } \\
\text { CL3: Recommend the product } \\
\text { to colleagues } \\
\text { CL4: Make the product the first } \\
\text { choice }\end{array}$ \\
\hline
\end{tabular}

\section{RESULTS AND ANALYSIS}

\subsection{Quantitative Data Analysis: Respondents' Profile}

From the 90 respondents who bought halal meat in the modern market, $40 \%$ was male respondents and $58.9 \%$ was female respondents. The most common age group was the 17-25 group with the percentage of $80 \%$. The most group for the education level variables is from the group of senior high school that is equal to $59 \%$. In occupation variable, the most occupation is the student group by $62 \%$.

\subsection{Descriptive Statistics Test}

\subsubsection{Halal Logistics Supplier Service Quality}

The dimension of information system availability has an average value of 4.745 . These results indicate that the average consumer agrees that the halal meat product providers already include a clear logo and halal certification in their products, but sometimes there are still products that have no halal information. A higher average score is found in the product availability dimension of 4.966. These results also indicate consumer agree that halal meat products are available with adequate quantities and variants in the modern market in Bali.

\subsubsection{Halal Logistics Performance}

The mean values for halal logistics performance variables ranged from 5.011 to 5.267. In general, these results show that halal logistics performance in halal meat products and the modern market in Bali is good enough. The first dimension of order quality gets an average score of 5.267 which prove that consumers agree that the quality of halal meat in the modern market is good enough. The dimension of personnel contact quality examines the quality of service of modern market staff who sells halal meat in Bali. The average value obtained by this dimension of 5.156 indicates that modern market staffs are willing and able to provide information with regard to halal meat products. 
The third dimension is information quality, which has an average value of 5.184. This value indicates the customer's consent to the certification and the halal logo that is present on the product is from a trusted source. The order condition dimension tests about good product conditions without any damage. The average value in this dimension is 5.233 indicating the condition of the product is in good condition when it is in the hands of consumers. The order of discrepancy dimension has an average value of 5.011 which is the lowest average among other halal logistics performance dimensions. However, this figure also indicates consumer approval that the average product has a product return/exchange guarantee.

\subsubsection{Perceived Service Value}

In the questionnaire presented to the customer, the questions of these variables indicate the consumer's opinion whether to get good service in accordance with the price. This dimension gets an average score of 5.239 out of 4 indicators in the questionnaire. These results suggest that halal meat consumers feel the quality of service and good purchasing experience of the modern market where they buy meat.

\subsubsection{Customer Satisfaction}

This variable has 3 indicators in the questionnaire that examines how the level of customer satisfaction on halal meat. An indicator of "good service" gets an average rating of 5.222. This average value is the same as the other two indicators, namely the price conformity with product and service indicator and consumer's feelings of pleasure which also get an average score of 5.222. These results indicate that halal meat consumers are already satisfied with the products and services they get.

\subsubsection{Customer Loyalty}

The average value of this variable is 5.231 which is derived from 4 indicators. The first indicator of giving opinion/positive comments gets an average score of 5.089. The second indicator is the purchase of the product again gets an average value of 5.267. The third indicator of product recommendation is 5.267. The fourth indicator of product selection as the first choice gets a value of 5.300. From these results, it can be concluded that consumers have a strong willingness to buy the product back and recommend it and make the product as the first choice.

\subsection{Outer Model Analysis}

\subsubsection{Convergent Validity}

A data is said to have good convergent validity if it has an outer loading value $>0.708$ (Hair Jr et al., 2016) and AVE value > 0.5. In this study, all indicators have good outer loading and AVE values. 
Table 2: Test Results Validity of Constructs Indicators and Variables

\begin{tabular}{|c|c|c|c|c|c|c|}
\hline Order & Variable & "Dimension & Indicator & $\begin{array}{l}\text { Outer } \\
\text { Loading }\end{array}$ & AVE & Status \\
\hline & & & CL1 & 0.868 & & Valid \\
\hline First & Customer & & CL2 & 0.945 & 0.833 & Valid \\
\hline \multirow{2}{*}{ Order } & Loyalty & & CL3 & 0.931 & & Valid \\
\hline & & & CL4 & 0.906 & & Valid \\
\hline \multirow{3}{*}{$\begin{array}{l}\text { First } \\
\text { Order }\end{array}$} & \multirow{3}{*}{$\begin{array}{l}\text { Customer } \\
\text { Satisfaction }\end{array}$} & & CS1 & 0.942 & & Valid \\
\hline & & & $\mathrm{CS} 2$ & 0.953 & 0.879 & Valid \\
\hline & & & $\mathrm{CS} 3$ & 0.918 & & Valid \\
\hline \multirow{7}{*}{$\begin{array}{l}\text { Second } \\
\text { Order }\end{array}$} & \multirow{7}{*}{$\begin{array}{l}\text { Halal } \\
\text { Logistic } \\
\text { Performance }\end{array}$} & & IQ1 & 0.972 & & Valid \\
\hline & & Information Quality & IQ2 & 0.964 & & Valid \\
\hline & & Order Condition & $\mathrm{OC} 1$ & 0.957 & & Valid \\
\hline & & Order Discrepancy & OD1 & 0.962 & 0.932 & Valid \\
\hline & & Order Quality & OQ1 & 0.957 & & Valid \\
\hline & & Personnel Contact & PCQ1 & 0.971 & & Valid \\
\hline & & Quality & PCQ2 & 0.975 & & Valid \\
\hline \multirow{5}{*}{$\begin{array}{l}\text { Second } \\
\text { Order }\end{array}$} & \multirow{5}{*}{$\begin{array}{l}\text { Halal } \\
\text { Supplier } \\
\text { Service } \\
\text { Quality }\end{array}$} & Information System & IS1 & 0.886 & \multirow{5}{*}{0.778} & Valid \\
\hline & & Availability & IS2 & 0.880 & & Valid \\
\hline & & \multirow{3}{*}{ Product Availability } & PA1 & 0.907 & & Valid \\
\hline & & & PA2 & 0.877 & & Valid \\
\hline & & & PA3 & 0.860 & & Valid \\
\hline \multirow{2}{*}{\multicolumn{2}{|c|}{$\begin{array}{l}\text { First } \\
\text { Order }\end{array}$}} & \multirow{2}{*}{ Information Quality } & IQ1 & 0.985 & \multirow{2}{*}{0.970} & Valid \\
\hline & & & IQ2 & 0.985 & & Valid \\
\hline \multirow{2}{*}{$\begin{array}{l}\text { First } \\
\text { Order }\end{array}$} & & Information System & IS1 & 0.966 & \multirow{2}{*}{0.932} & Valid \\
\hline & & Availability & IS2 & 0.965 & & Valid \\
\hline \multicolumn{2}{|l|}{$\begin{array}{l}\text { First } \\
\text { Order }\end{array}$} & Order Condition & $\mathrm{OC} 1$ & 1.000 & 1.000 & Valid \\
\hline \multicolumn{2}{|l|}{$\begin{array}{l}\text { First } \\
\text { Order }\end{array}$} & Order Discrepancy & OD1 & 1.000 & 1.000 & Valid \\
\hline \multicolumn{2}{|l|}{$\begin{array}{l}\text { First } \\
\text { Order }\end{array}$} & Order Quality & OQ1 & 1.000 & 1.000 & Valid \\
\hline \multirow{11}{*}{$\begin{array}{l}\text { First } \\
\text { Order }\end{array}$} & & Perceived Service & PSV1 & 0.913 & \multirow{5}{*}{0.789} & Valid \\
\hline & & Value & & & & \\
\hline & & & PSV2 & 0.901 & & Valid \\
\hline & & & PSV3 & 0.907 & & Valid \\
\hline & & & PSV4 & 0.880 & & Valid \\
\hline & & Personnel Contact & PCQ1 & 0.988 & \multirow{3}{*}{0.977} & Valid \\
\hline & & Quality & & & & \\
\hline & & & PCQ2 & 0.989 & & Valid \\
\hline & & \multirow[t]{3}{*}{ Product Availability } & PA1 & 0.936 & \multirow{3}{*}{0.842} & Valid \\
\hline & & & PA2 & 0.930 & & Valid \\
\hline & & & PA3 & 0.886 & & Valid \\
\hline
\end{tabular}

The first way of measuring discriminant validity is by comparing the AVE root values of each construct with the correlation values among other constructs in the model (Fornell-Larcker 
criterion) Ghozali (2008). The second way is to check the cross-load value of each construct. If this value of the construct is higher than the other, then it can be said that the construct has a good discriminant validity value.

Table 3: Discriminant Validity Test Results (Fornell-Larcker Criterion) Constructs

\begin{tabular}{cccccccccccc}
\hline & CL & CS & HLP & IQ & IS & OC & OD & OQ & PA & PCQ & PSV \\
\hline CL & 0.91 & & & & & & & & & & \\
CS & 0.87 & 0.94 & & & & & & & & & \\
HLP & 0.75 & 0.74 & 0.97 & & & & & & & & \\
IQ & 0.71 & 0.69 & 0.98 & 0.99 & & & & & & & \\
IS & 0.50 & 0.53 & 0.61 & 0.60 & 0.97 & & & & & & \\
OC & 0.73 & 0.72 & 0.96 & 0.93 & 0.61 & 1.00 & & & & & \\
OD & 0.71 & 0.70 & 0.96 & 0.93 & 0.60 & 0.91 & 1.00 & & & & \\
OQ & 0.75 & 0.73 & 0.96 & 0.92 & 0.59 & 0.89 & 0.91 & 1.00 & & & \\
PA & 0.61 & 0.63 & 0.71 & 0.68 & 0.77 & 0.72 & 0.70 & 0.73 & 0.92 & & \\
PCQ & 0.74 & 0.74 & 0.98 & 0.95 & 0.58 & 0.93 & 0.93 & 0.94 & 0.68 & 0.99 & \\
\hline \hline
\end{tabular}

Fornell-Larcker test results show that the halal logistics performance variable is not eligible because the AVE root value of the halal logistics performance variable is not greater than the correlation between the other constructs. The AVE root of the halal variable of service quality suppliers is also no greater than the correlation between the other constructs. Therefore, the second test will be done by cross loading. The test results show the cross loading value of each construct has the highest value in the construct. So it can be concluded that the research model has met the discriminant validity.

\subsubsection{Discriminant Validity}

\subsubsection{Cronbach Alpha and Composite Reliability}

Reliability of the questionnaire was tested with two criteria, namely Cronbach alpha and composite reliability. Cronbach alpha assesses internal consistency and correlation between variables (Hair Jr et al., 2016). Cronbach alpha value must be more than 0.70 for an indicator can be said reliable. Composite reliability emphasizes the identification of shared factors built from a set of items (Widhiarso, 2013). The range of values of $0.6-0.7$ is acceptable and more preferably in the range 0.7 - 0.9 (Bernstein \& Nunnally, 1994). Test results show that all indicators are reliable.

Table 4: Reliability Test Results With Composite Reliability and Cronbach's Alpha Value.

\begin{tabular}{lccc}
\hline \hline \multicolumn{1}{c}{ Laten Variable } & $\begin{array}{c}\text { Composite } \\
\text { Reliability }\end{array}$ & Cronbach Alpha & Status \\
\hline Customer Loyalty & 0.952 & 0.933 & Reliable \\
\hline Customer Satisfaction & 0.956 & 0.931 & Reliable \\
\hline Halal Logistic Performance & 0.990 & 0.988 & Reliable \\
\hline
\end{tabular}




\begin{tabular}{llll}
\hline \hline $\begin{array}{l}\text { Halal Supplier Service } \\
\text { Quality }\end{array}$ & 0.946 & 0.929 & Reliable \\
\hline Information Quality & 0.985 & 0.969 & Reliable \\
\hline Information System & 0.965 & 0.927 & Reliable \\
\hline Order Condition & 1.000 & 1.000 & Reliable \\
\hline Order Discrepancy & 1.000 & 1.000 & Reliable \\
\hline Order Quality & 1.000 & 1.000 & Reliable \\
\hline Perceived Service Value & 0.933 & 0.893 & Reliable \\
\hline Personnel Contact Quality & 0.988 & 0.977 & Reliable \\
\hline Product Availability & 0.941 & 0.906 & Reliable \\
\hline \hline
\end{tabular}

\subsection{Inner Model Analysis}

\subsubsection{The Coefficient of Determination (R-squared)}

$\mathrm{R}$-square values are used to assess how certain latent independent variables have substantive influence on latent depandent variables (Bastian, 2014). The endogenous latent variable criterion for the R-square value is "good" if it reaches 0.67 , "moderate" if it reaches 0.33 , and "weak" if the $\mathrm{R}$-squared value is only 0.19 . The output of R-squared after tested is as follows:

Table 5: R-squared Test Results

\begin{tabular}{lc}
\hline \hline \multicolumn{1}{c}{ Variable } & R square \\
\hline Customer Loyalty & 0.753 \\
Customer Satisfaction & 0.681 \\
Halal Logistic Performance & 0.511 \\
Perceived Service Value & 0.517 \\
\hline \hline
\end{tabular}

Table 5 shows that R-squared values that include moderate are on the variable of halal logistics performance and perceived service value. Halal logistics performance variable has R-squared value equal to 0.511 , it means that halal logistics performance variable can be explained by halal supplier service quality equal to $51.1 \%$, and the rest $48.9 \%$ not explained in this research. A value of 0.517 is the coefficient of determination of perceived service value variable, which means that perceived service value can be explained by the halal supplier service quality variable of $51.7 \%$, while the remaining $48.3 \%$ is not explained in this study.

Another variable has a good R-squared value because it has a value greater than 0,67 . Value of determination coefficient of customer satisfaction equal to 0.681 , meaning perceived service value and halal logistics performance have proportion equal to $68.1 \%$ and rest $31.9 \%$ not explained in this research. Customer loyalty has a coefficient of determination of 0.753 , meaning that customer satisfaction variable has a proportion of $75.3 \%$ and the remaining $24.7 \%$ is not described in this study. 


\subsection{2. $\quad$ Estimates for Path Coefficient}

The path coeffiecient serves to assess the relationship between the latent variables described through the standard coefficient unit of measurement values (Joe F Hair, Ringle, \& Sarstedt, 2011). The criterion of the value for the path coefficient is 3 , namely: 1 ) if the value is less than 0.15 , it is considered weak; 2 ) values between 0.15 to 0.45 are considered moderate; 3 ) values over 0.45 are considered strong (Cohen, 1992). The value of path coefficient between variables having strong relation $(>0.45)$ has $\mathrm{P}$ value $<$ sig value $(\alpha=0.05)$ which means there is significance between the related variables, while the path coefficient value between variables having medium relationship $(0.15-0.45)$ and weak $(<0.15)$ has a value of $\mathrm{P}>\operatorname{sig}$ value. $(\alpha=0.05)$ which means there is no significance between the related variables.

Table 6: Path Coefficient t-Test Results

\begin{tabular}{llll}
\hline \hline & Path Coeff & tvalue $_{\text {value }}$ & \multicolumn{1}{c}{ pvalu } \\
\hline Customer Satisfaction > Customer Loyalty & 0.868 & 27.756 & 0.000 \\
Halal Logistic Performance > Customer Satisfaction & 0.358 & 2.497 & 0.013 \\
Perceived Service Value > Customer Satisfaction & 0.551 & 3.832 & 0.000 \\
Halal Supplier ServQual > Customer Satisfaction & -0.030 & 0.214 & 0.830 \\
Halal Supplier ServQual > Halal Logistic Performance & 0.715 & 9.748 & 0.000 \\
Halal Supplier ServQual > Perceived Service Value & 0.719 & 8.800 & 0.000 \\
\hline \hline
\end{tabular}

Based on the theory, the path coefficient between halal supplier service quality and customer satisfaction is considered as a weak relationship because it has a negative value and less than 0.15. The negative numbers indicate that the relationship between halal supplier service quality and customer satisfaction is not unidirectional or not directly proportional.

A moderate path coefficient is shown by the relationship between halal logistics performance and customer satisfaction, with a value of 0.358 . The relationship between these variables is also unidirectional because it has a positive value. As for the results of other path coefficient test showed a strong and positive relationship because it has a value greater than 0.45 and a positive number.

\subsubsection{Hypotheses Testing Results}

Based on the results of $t_{\text {value }}$ and $p_{\text {value }}$ in table 7 show that not all hypotheses are proven. This section discusses the proof of hypothesis based on the value of tvalue and palue in table 7 . The hypothesis to be tested can be seen in literature review section. The first hypothesis states that halal supplier's service quality positively affects the halal logistics performance. Based on path coefficient test results, between halal supplier's service quality and halal logistics performance can be found $t_{\text {value }}$ of 9.748 and $p_{\text {value }}$ of 0.000 . The $t_{\text {value }}=9.748$ shows greater than $1.96\left(t_{\text {table }}\right)$, whereas the p-value $=0.000$ value is smaller than 0.05 (sig. $5 \%)$. These results show that hypothesis 1 proved that halal supplier's service quality has a positive and significant effect on halal logistics service performance.

The second hypothesis of halal supplier's service quality has a positive effect on perceived service value. From table 7 , it can be seen that the tvalue and pvalue from the halal supplier's service quality to the perceived service value of 8.800 and 0.000 . The value of $t_{\text {value }}=8.800$ is greater than 
1.96 (table) and the value of $p_{\text {value }}=0.000$ is smaller than 0.05 (sig. $\left.5 \%\right)$. From this result, it can be concluded that hypothesis 2 can be proved that halal supplier's service quality has a positive and significant influence on perceived service value.

The third hypothesis is about the quality of halal supplier service to customer satisfaction. The value of tvalue is 0.214 and $p_{\text {value }}$ has a value of 0.830 . The value of tvalue $=0.214$ is smaller than 1.96 (ttable) and the value of $p_{\text {value }}=0.830$ is greater than 0.05 ( $\operatorname{sig} 5 \%$ ). These figures show no significant influence between the quality of halal supplier service and customer satisfaction. This suggests the latter hypothesis is not proven.

The next hypothesis tries to find out whether halal logistics performance has a positive effect on customer satisfaction. Test results between these 2 variables can be seen from the tvalue value of 2.497 which is greater than table (1.96) and pvalue of 0.013 which is smaller than 0.05 (sig. $5 \%$ ). These results indicate the value of $t_{\text {value }}$ and $p_{\text {value }}$ values are eligible so that halal logistics performance is concluded to have a positive and significant effect on customer satisfaction.

The fifth hypothesis states that perceived service value has a positive effect on customer satisfaction. Perceived service value with customer satisfaction has a $t_{\text {value }}$ of 3.832 which is greater than 1.96 ( $\mathrm{t}_{\text {table}}$ ) and $\mathrm{p}_{\mathrm{value}}$ value of 0.000 which is smaller than 0.05 (sig. 5\%). With this result, it can be said that perceived service value has a positive and significant effect on customer satisfaction or in other words concluded that the fifth hypothesis proved.

The sixth hypothesis looks for linkages between customer satisfaction and customer loyalty. From the results found the value of $t_{\text {value }}$ equal to 27.756 which is bigger than $t_{\text {table }}(11.96)$ and $p_{\text {value }}$ has a value of 0.000 smaller than 0.05 (sig. 5\%). It can be concluded that customer satisfaction has a positive and significant effect on customer loyalty and it is concluded that the sixth hypothesis is proven.

Table 7: Hypotheses Testing Results

\begin{tabular}{clccc}
\hline \hline Hypothesis & \multicolumn{1}{c}{ Path } & t $_{\text {VALUE }}$ & PVALUE & Result \\
\hline H1 & $\begin{array}{l}\text { Halal supplier's service quality }> \\
\text { Halal logistic service performance }\end{array}$ & 9.748 & 0.000 & supported \\
\hline H2 & $\begin{array}{l}\text { halal supplier's service quality }> \\
\text { perceived service value }\end{array}$ & 8.800 & 0.000 & supported \\
\hline H3 & $\begin{array}{l}\text { halal supplier's service quality > } \\
\text { customer satisfaction }\end{array}$ & 0.214 & 0.830 & $\begin{array}{c}\text { Not } \\
\text { supported }\end{array}$ \\
\hline H4 & $\begin{array}{l}\text { halal logistic performance } \\
\text { customer satisfaction } \\
\text { perceived service value > customer } \\
\text { satisfaction }\end{array}$ & 2.497 & 0.013 & supported \\
\hline H5 & $\begin{array}{l}\text { customer satisfaction > customer } \\
\text { loyalty }\end{array}$ & 27.756 & 0.000 & supported \\
\hline H6 & & & & supported \\
\hline \hline
\end{tabular}




\section{DISCUSSION}

The findings of the quantitative tests result in the conclusion whether the proposed hypotheses can be proven or not. The proven hypotheses can be seen from the value of $t$ and the palue sufficient to be considered significant. These results are also supported by previous studies which have relevant results with the hypothesis test results.

\subsection{Halal Supplier's Service Quality to Halal Logistics Performance (H1)}

Halal supplier service quality is a measurement used to measure service quality. In this research model, halal supplier service quality positively influences to halal logistics performance. It is also tested in data obtained from quantitative tests. The $t$ and $p$ value for the $H 1$ test reached a significant level, proving that there is an influence between halal supplier's service quality and halal logistics performance. Previous research such as research by Liang (2008) also proves that halal supplier's service quality positively affects halal logistics performance.

The quality of halal supplier services that has 2 dimensions, namely product availability and information system availability, is recognized by the sample of respondents interviewed, both of which have a major influence on halal logistics performance. Stores that provide complete halal product variants and are accompanied by halal status information, usually also provide qualified personnel, have a warranty return policy, pay attention to the conditions and good quality of the product.

For respondents, a positive influence also occurs on their tendency to get satisfaction from the product purchased. Consumers feel happy and satisfied if the shop where they make a purchase provides complete halal meat products, and is accompanied by halal information in the form of logos and halal certification. Both of these variables are moderated by halal logistics performance which also serves to measure whether the quality of services provided has given satisfaction to customers. It is important for providers of halal meat products, that complete product availability and the existence of a good information system strongly support the creation of customer satisfaction which leads to increased purchases.

\subsection{Halal Supplier's Service Quality to Perceived Service Value (H2)}

Based on previous research, perceived service value is positively influenced by service quality ( $\mathrm{S}$. Y. Lee, 2006; Tam, 1999). This is the basis of the second hypothesis that the quality of halal supplier services has a positive effect on perceived service value. This is in line with the data of quantitative test results that support the hypothesis. Significant value of $t$ and $p$ values prove the influence between the quality of halal supplier services and perceived service value. Halal supplier's service quality is a variable that measures the quality of service while perceived service value is a judgment made by consumers about the experience of using products, namely halal meat products. Therefore, it is very reasonable if the quality of services provided by service providers is very influential on the value of services perceived by consumers.

This can be seen in stores that provide good service quality, which directs respondents to rate products according to their needs (service indicator values that are felt to be good) make respondents feel satisfied with the store. Because consumers' basic needs are trust in halal 
guarantees, and the willingness to consume products in accordance with their expectations (availability of various products), it will be a very positive effect if halal meat providers can provide good information that the product is halal. Fulfillment of consumer desires will attract the attention of consumers and ultimately will get customer satisfaction( $\mathrm{Wu}, \mathrm{Wei}, \& \mathrm{Chen}, 2008)$. This positive influence will encourage halal meat providers to pay attention to the quality of services to support the sale of their products. That's because not only does the quality of halal supplier services have an effect on halal logistics performance, these variables also affect the perceived value of services, which ultimately leads to customer satisfaction.

\subsection{Halal Supplier's Service Quality to Customer Satisfaction (H3)}

The quality of halal supplier services is the quality of service provided by suppliers to consumers. Ketikidis et al. (2006) and Yang et al. (2006) concluded that service quality can improve operational performance directly or indirectly (through logistical performance) which results in customer satisfaction. However, in this study, However, in this study, the quality of halal supplier services did not have a significant effect on customer satisfaction. The value of $t$ and the value of $\mathrm{p}$ are not significant, so it can be concluded that between the quality of service of halal supplier and customer satisfaction has an inverse relationship. It means that the quality of halal supplier services only has a weak influence to directly generate customer satisfaction. However, there is a strong influence on customer satisfaction indirectly (through halal logistics performance and perceived service value). The cause can be traced from interview respondents, where respondents in the majority of non-Muslim areas are more confident to choose products if they are accompanied by values and attributes that enhance their trust in halal products, such as reliable halal logos, communicative sales staff, and comparable to the efforts they make to get the product. In fact, all respondents stated that the staff / seller factor was a very influential point in purchasing decisions. So it can be concluded that without being supported by perceived service value and halal logistics performance, a sense of "security" would not occur if the store only provided service quality.

\subsection{Halal Logistics Performance to Customer Satisfaction (H4)}

Previous study by Ellinger et al.(2000) stated that logistics performance has a positive effect on customer satisfaction. In this study, the value of $t$ and $p$ value in the results of this hypothesis test reached a significant value. This proves the influence of halal logistics performance on customer satisfaction. Halal logistics performance has 5 dimensions taken from the criteria compiled by Mentzer et al. (2001) were then modified based on the characteristics of retailer services by Siu and Cheung (2001). The 5 dimensions used in this study: order condition, order discrepancy, order quality, personnel contact quality, and information quality.

Based on the results the quantitative test, it is concluded that halal meat providers not only need to provide good service quality but also need to provide 5 dimensions in terms of logistics performance well to support customer satisfaction. This is also seen in the study of Liang (2008) which shows a positive relationship between halal logistics performance and customer satisfaction.

\subsection{Perceived Service Value to Customer Satisfaction (H5)}

The perceived service value is an important factor in marketing, which will lead to customer satisfaction (Gallarza \& Saura, 2006). The results of quantitative tests in this study also proved that 
between perceived service value and customer satisfaction have a positive relationship. The value of $t$ and the $p$ value of the test result give a positive and significant result for this hypothesis. This should be an important concern for halal meat providers that if they fail to provide a good perceived service value, then sales will not increase as consumers feel dissatisfied.

\subsection{Customer Satisfaction to Customer Loyalty (H6)}

The hypothesis related to customer satisfaction which has a positive influence on customer loyalty in this study is based on previous research. Customer satisfaction contributes to an important role in consumer behavior which is a characteristic of loyalty such as positive repurchase intention and feedback (Sivadas \& Baker-Prewitt, 2000). The results of this study are also in line with that research as evidenced by the value of $\mathrm{R}$ square of customer loyalty is 0.753 which means that customer satisfaction form $75.3 \%$ of customer loyalty. In addition, $t$ value and $p$ value also indicate that customer satisfaction has a significant effect to customer loyalty. Things that need to be considered by halal meat providers are very important to provide halal logistics performance, perceived service value, as well as good quality service of halal suppliers, to increase customer satisfaction.

\section{CONCLUSION}

The study about the influence of halal supplier's service quality, halal logistics performance, perceived service value and customer satisfaction to customer's loyalty on halal meat products at non-Moslem areas are playing an important role in developing Muslim countries. This study focuses on the effect of halal logistics performance on customer loyalty for Indonesian consumer context and the finding found that halal logistics performance, perceived service value, and also halal good supplier's service quality, to improve consumer satisfaction has a positive effect on customer loyalty.

There are 6 hypotheses that proposed in this study were tested in quantitative approaches. The results show that 5 of 6 hypotheses are proven. Significant influence occurs on the relationship halal supplier's service quality to halal logistics performance, halal supplier's service quality to perceived service value, halal logistics performance to customer satisfaction, perceived service value to customer satisfaction, and customer satisfaction to customer loyalty. On the other hand, different results explain that there is no significant relationship between the quality of halal supplier services and customer satisfaction. Further research that can be developed from this study is related to the readiness to use halal technology and its effect on halal logistics performance and customer satisfaction.

\section{REFERENCES}

Ali, A., Xiaoling, G., Sherwani, M., \& Ali, A. (2017). Factors affecting Halal meat purchase intention: Evidence from international Muslim students in China. British Food Journal, $119(3), 527-541$.

Alqudsi, S. G. (2014). Awareness and demand for 100\% halal supply chain meat products. Procedia - Social and Behavioral Sciences, 130, 167-178. doi: http://dx.doi.org/10.1016/ j.sbspro.2014.04.021 
Awan, H. M., Siddiquei, A. N., \& Haider, Z. (2015). Factors affecting Halal purchase intentionEvidence from Pakistan's Halal food sector. Management Research Review, 38(6), 640660.

Bastian, D. A. (2014). Analisa pengaruh citra merek (brand image) dan kepercayaan merek (brand trust) terhadap loyalitas merek (brand loyalty) ades pt. ades alfindo putra setia. Jurnal Strategi Pemasaran, 2(1), 1-9.

Bernstein, I. H., \& Nunnally, J. (1994). Psychometric theory. Journal of Marketing, 56, 83-95.

Bienstock, C. C., Mentzer, J. T., \& Bird, M. M. (1997). Measuring physical distribution service quality. Journal of the Academy of Marketing Science, 25(1), 31-44.

Bienstock, C. C., Royne, M. B., Sherrell, D., \& Stafford, T. F. (2008). An expanded model of logistics service quality: Incorporating logistics information technology. International Journal of Production Economics, 113(1), 205-222.

Bowersox, D. J., Closs, D. J., \& Cooper, M. B. (2002). Supply chain logistics management (Vol. 2): McGraw-Hill New York, NY.

Cachon, G. P., \& Feldman, P. (2015). Price commitments with strategic consumers: Why it can be optimal to discount more frequently... than optimal. Manufacturing \& Service Operations Management, 17(3), 399-410.

Chen, Q., \& Wells, W. (2000). Consumer satisfaction and dissatisfaction: One or two constructs? Advances in Consumer Research, 28, 34-39.

Cohen, J. (1992). A power primer. Psychological bulletin, 112(1), 155.

Davis, E. R. (2006). The role of logistics service quality in creating customer loyalty.

Duygun, A. (2015). The impacts of customer loyalty on negative word-of-mouth communication and repurchase intention. Journal of Marketing and Management, 6(1), 16.

Ellinger, A., Daugherty, P., \& Keller, S. (2000). The relationship between marketing/logistics. Journal of Business Logistics, 21(1).

Fang, J., George, B., Shao, Y., \& Wen, C. (2016). Affective and cognitive factors influencing repeat buying in e-commerce. Electronic Commerce Research and Applications, 19, 4455.

Gallarza, M. G., \& Saura, I. G. (2006). Value dimensions, perceived value, satisfaction and loyalty: An investigation of university students' travel behaviour. Tourism Management, 27(3), 437-452.

Ghozali, I. (2008). Structural Equation Modeling Metode Alternatif dengan Partial Least Square. Semarang: Badan Penerbit Universitas Diponegoro.

Hair, J. F., Black, W. C., Babin, B. J., Anderson, R. E., \& Tatham, R. L. (2006). Multivariate data analysis 6th Edition. New Jersey: Pearson Education.

Hair, J. F., Ringle, C. M., \& Sarstedt, M. (2011). PLS-SEM: Indeed a silver bullet. Journal of Marketing theory and Practice, 19(2), 139-152.

Jaafar, H. S., Faisol, N., Rahman, F. A., \& Muhammad, A. (2016). Halal logistics versus halal supply chain: A preliminary insight Contemporary Issues and Development in the Global Halal Industry (pp. 579-588): Springer.

Jusmaliani, J., \& Nasution, H. (2009). Religiosity aspect in consumer behaviour: Determinants of halal meat consumption. ASEAN Marketing Journal, 1, 1-11.

Kalantari Shahijan, M., Rezaei, S., Nigel Preece, C., \& Khairuzzaman Wan Ismail, W. (2014). Examining retailers' behaviour in managing critical points in Halal meat handling: A PLS analysis. Journal of Islamic Marketing, 5(3), 446-472.

Keaveney, S. M. (1995). Customer switching behavior in service industries: An exploratory study. The Journal of Marketing, 71-82. 
Ketikidis, P. H., Lenny Koh, S., Gunasekaran, A., Cheung, C., Chan, Y., Kwok, S., .. . Wang, W. (2006). A knowledge-based service automation system for service logistics. Journal of Manufacturing Technology Management, 17(6), 750-771.

Kisperska-Moron, D. (2005). Logistics customer service levels in Poland: Changes between 1993 and 2001. International Journal of Production Economics, 93, 121-128.

La, K. V. (2005). Customer Loyalty in Web-based Retailing. (Doctor of Philosophy), Royal Melbourne Institute of Technology, Melbourne.

Lee, C. K., Yoon, Y. S., \& Lee, S. K. (2007). Investigating the relationships among perceived value, satisfaction, and recommendations: The case of the Korean DMZ. Tourism Management, 28(1), 204-214.

Lee, S. Y. (2006). A conceptual model of the roles of price, quality, and intermediary constructs in determining behavioral intention to visit a festival. Texas A\&M University.

Lever, J., \& Miele, M. (2012). The growth of halal meat markets in Europe: An exploration of the supply side theory of religion. Journal of Rural Studies, 28(4), 528-537.

Liang, H. C. (2008). Impact of Logistic Service Performance on Tourist Satisfaction and Loyalty. RMIT University, Melbourne.

Lin, H. H., \& Wang, Y. S. (2006). An examination of the determinants of customer loyalty in mobile commerce contexts. Information \& management, 43(3), 271-282.

Man, Y. S. (2006). Performance Measurement and Management of Third Party Logistics: An Organizational Theory Approach. Hong Kong Baptist University.

Masudin, I., Fernanda, F., Jie, F., \& Djajadikerta, H. (2018). Muslim and non-muslim perceptions on Halal Meat Logistics (HML). Paper presented at the IOP Conference Series: Materials Science and Engineering.

Masudin, I., Fernanda, F. W., \& Widayat, W. (2018). Halal logistics performance and customer loyalty: From the literature review to a conceptual framework. International Journal of Technology, 10(1), 1072-1084.

Mentzer, J. T., Flint, D. J., \& Hult, G. T. M. (2001). Logistics service quality as a segmentcustomized process. Journal of marketing, 65(4), 82-104.

Mentzer, J. T., Flint, D. J., \& Kent, J. L. (1999). Developing a logistics service quality scale. Journal of Business Logistics, $20(1), 9$.

Mentzer, J. T., Myers, M. B., \& Cheung, M. S. (2004). Global market segmentation for logistics services. Industrial Marketing Management, 33(1), 15-20.

Mentzer, J. T., Rutner, S. M., \& Matsuno, K. (1997). Application of the means-end value hierarchy model to understanding logistics service value. International Journal of Physical Distribution \& Logistics Management, 27(9/10), 630-643.

Mentzer, J. T., \& Williams, L. R. (2001). The role of logistics leverage in marketing strategy. Journal of Marketing Channels, 8(3-4), 29-47.

Novack, R. A., Rinehart, L. M., \& Langley Jr, C. J. (1994). An internal assessment of logistics value. Journal of Business Logistics, 15(1), 113.

Olya, H. G. T., \& Al-ansi, A. (2018). Risk assessment of halal products and services: Implication for tourism industry. Tourism Management, 65, 279-291. doi: https://doi.org/10.1016/ j.tourman.2017.10.015

Richey, R. G. (2003). Technological readiness and strategic interactive fit: Dynamic capabilities impacting logistics service competency and performance.

Richey, R. G., Daugherty, P. J., \& Roath, A. S. (2007). Firm technological readiness and complementarity: capabilities impacting logistics service competency and performance. Journal of Business Logistics, 28(1), 195-228. 
Rinehart, L. M., Cooper, M. B., \& Wagenheim, G. D. (1989). Furthering the integration of marketing and logistics through customer service in the channel. Journal of the Academy of Marketing Science, 17(1), 63-71.

Siu, N. Y., \& Cheung, J. T. K. (2001). A measure of retail service quality. Marketing Intelligence \& Planning, 19(2), 88-96.

Sivadas, E., \& Baker-Prewitt, J. L. (2000). An examination of the relationship between service quality, customer satisfaction, and store loyalty. International Journal of Retail \& Distribution Management, 28(2), 73-82.

Stank, T. P., Goldsby, T. J., Vickery, S. K., \& Savitskie, K. (2003). Logistics service performance: estimating its influence on market share. Journal of Business Logistics, 24(1), 27-55.

Stitou, N., \& Rezgui, H. (2012). The Muslim Consumer as the Key Player in Halal: ASIDCOM.

Tam, J. L. (1999). The effects of service quality, perceived value and customer satisfaction on behavioral intentions. Journal of Hospitality \& Leisure Marketing, 6(4), 31-43.

Tieman, M., Ghazali, M. C., \& Van Der Vorst, J. G. (2013). Consumer perception on halal meat logistics. British Food Journal.

Um, S., Chon, K., \& Ro, Y. (2006). Antecedents of revisit intention. Annals of Tourism Research, 33(4), 1141-1158.

Wang, E. S.-T., Yu, J.-R., \& Griffith, C. (2016). Effect of product attribute beliefs of ready-todrink coffee beverages on consumer-perceived value and repurchase intention. British Food Journal, 118(12).

Wang, Y., Po Lo, H., Chi, R., \& Yang, Y. (2004). An integrated framework for customer value and customer-relationship-management performance: a customer-based perspective from China. Managing Service Quality: An International Journal, 14(2/3), 169-182.

Widhiarso, W. (2013). Estimasi Reliabilitas Pengukuran dalam Pendekatan Model Persamaan Struktural.

Wong, W. P. M., Lo, M. C., \& Ramayah, T. (2014). The effects of technology acceptance factors on customer e-loyalty and e-satisfaction in Malaysia. International Journal of Business and Society, 15(3), 477.

Wu, S. I., Wei, P. L., \& Chen, J. H. (2008). Influential factors and relational structure of internet banner advertising in the tourism industry. Tourism Management, 29(2), 221-236.

Ya'kob, S. A., \& Jusoh, W. J. W. (2016). The effect of supply chain lingkage on micro and small enterprises' performance. International Journal of Business and Society, 17(1).

Yang, Y., Humphreys, P., \& McIvor, R. (2006). Business service quality in an e-commerce environment. Supply Chain Management: An International Journal, 11(3), 195-201. 